\title{
The Conversion of Muallaf to Islam in Selangor: Study on Behavior and Encouragement
}

\author{
Mariam Abd Majid ${ }^{1}$ \\ Syarul Azman Shaharuddin 1 \\ Abur Hamdi Usman ${ }^{1}$ \\ Fakhri Sungit ${ }^{1}$
}

${ }^{1}$ Faculty of Islamic Civilization Studies, International Islamic University College Selangor (KUIS), Malaysia Corresponding Author Email: aburhamdi@kuis.edu.my

\section{Doi:10.5901/mjss.2016.v7n3s1p19}

\section{Abstract}

This paper suggests a boost factor of muallaf behavior and some factors that motivate them to convert into Islam in Selangor. The data obtained through the method of documentation, interviews, and questionnaire were analyzed using inductive and deductive methods. The sample of study are selected using purposive sampling technique. This paper reveals the religious factor, psychosocial and bio-psychosocial which had encouraged muallaf to convert to Islam. In Selangor contextually, the dominant factor that prompted muallaf to embrace Islam was religion as they belief its truth and can be found directly nor for research. Moreover, by observation and inspiration or dream had became major boost for muallaf to accept Islam. This study found that the absence of information and do not receive accurate information about Islam were among the factors that causing delay in da'wah acceptance by non-muslim.

Keywords: Motivation, Behavior, Muallaf, Selangor, Malaysia

\section{Muallaf (The Convert) In Selangor: An Introduction}

Islamization is a huge movement toward a person due to its meaning to involve the migration of faith and principles which undoubtedly requires variety of tests and sacrifices. In Malaysia, the term of muallaf is fondly called 'our brother', 'new brother' or 'Muslim brother'. As muallaf or convert, they cannot run away from the challenges in the realm of life certainly (Tarimin et. al, 2010).

Muallaf refers to those who tend to Islam by doing well to them (Anon, 1970: 45). Apostasy is often associated with the muallaf due to their beliefs is still not very strong and they failed to adapt new situations, and in another case, they disappointed with the foreign environment (Seng, 2009). The reality proves that muallaf among the targets of da'wah (propaganda) that must be addressed through counseling, support and assistance in various aspects, such as education, emotional, social, and economic life to facing new challenges (Kose, 1996). Sayyid Qutb (1906-1966) an Egyptian author, educator, Islamic theorist, poet, and the leading member of the Egyptian Muslim Brotherhood in his book Tafsir Fi Zilal alQuran categorizes muallaf into three groups of individuals; (i) Who embrace Islam and with charity they accepted is expected to strengthen their positions towards Islam, (ii) Who have not yet converted to Islam and by receiving zakat (charity) is expected can soften their hearts to embrace Islam, (iii) Who have converted to Islam and sticking with it and through the provision of zakat, they are expected to appeal to people like them among their people to embrace Islam after seeing his brother receiving lots of help. The giving of zakat reflects the fact perfection of wisdom of God in administering the affairs of His servants at every aspect of the situation and the environment (Qutb, 1998; Dennet, 1950).

In addition, Wahbah al-Zuhaily (1932-2015) a prominent and Islamic scholar specializing in Islamic law and legal philosophy on his Tafsir Al-Munir interprets muallaf as those who had converted to Islam but their intentions towards Islam is still weak and their hearts must be tamed. This interpretation also refers to those who have the honor of giving zakat due to this group will cause them to protect and defend Islam (Al-Zuhaily, 1998). This interpretation also clarifies that muallaf are divided into two groups, those who had converted to Islam and who have not yet converted to Islam.

In Selangor, the titles of muallaf is used to someone who has embraced Islam for five years starting from the date and year of his registration of their converts to MAIS (the Selangor Islamic Religious Council). By Selangor Fatwa which dated on October 25, 2007, the convert will carry the name muallaf after 5 years by 'uruf (custom) provided that they has 
been joining the religion classes that are recognized or organized by MAIS. Moreover, MAIS is responsible for financing the cost of learning for this newly convert. Selangor Fatwa decided that in five years, a person muallaf can manage themselves if they are committed to follow each classes organized in each district, attend courses and programs which organized by the MAIS.

\section{Encouragement of Human Behavior: Literature Review}

There are various theories that explain the relationship between motivation and the factors that drive the actions or conduct of human (Piaget, 1970). Motivation can be understood as an attempt and motion of an action or behavior that is oriented to a goal targeted. Motivation influences the behavior of the human person There is a significant, permanent or ignored (Weiner, 1992; Maslow, 1943).

The theory of motivation has explained that every human behavior has a cause and not a coincidence (Redzuan, 2001). The process begins with the birth of motivation or desire that there is a need in the soul. The wanted and needs that exist in a person is pushing for action to meet those needs. The feeling of satisfaction appears in person when its requirements can be met (Huffman et.al, 1994). The need that exists can determine the goals to be achieved by a human being. Clear goals capable of mobilizing people's behavior in order to achieve a desired goal or expected (Husain, 1996). Figure 1 explains motivation process towards human behavior.

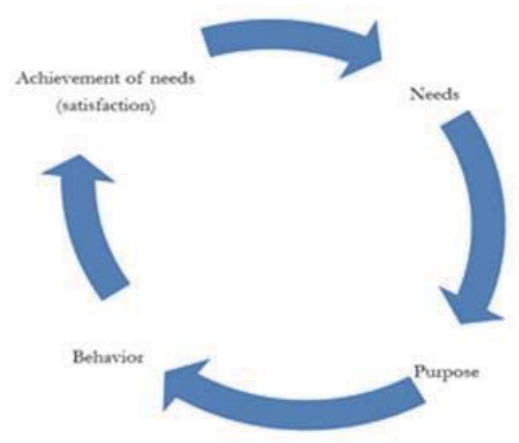

Figure 1. Motivation process towards human behavior.

The achievement of a goal targeted by human is an end to a cycle of motivation as well as being able to put the individual in the sense of complacency. Conversely, if a specified target cannot be met, the person will continue to strive to act so as to achieve the goals that have been targeted (Moore, 2008).

\subsection{Needs and Goals in Motivating the Human Behavior}

Psychologists have argued that the motive in an individual is a goal to be achieved. The goal is realized by the action that disclosed by its behavior (Harackiewicz et.al, 1997; Carlson, 2000). Normally, human would have committed itself in the pursuit of a goal which gives meaning to him (Carver and Scheier, 2003). Psychologists explain among the goals that exist within an individual that will provide motivation for the actions or behavior of an individual human being is (Mohamed, 1992):

\subsubsection{Motivation of fulfilling the biological needs}

Human will always strive to meet their biological needs (Maslow, 1987). Among the requirements to meet the goal of human biological needs is to meet the instinct requirement and maintain their stability (Millikan, 1984).

\subsubsection{Meeting the needs of instinct}

Instinct motivational theory suggests that human tends to do something to meet the needs or demands of his instincts. 
Energy instinct is in an impetus to the action of the human being. Instinct is something that is not learned but acquired by nature or natural. The goal is to meet the instinct requirements described as when a mother who tried to get a cure for her kids illness. Action to find a drug to treat a disease experienced by children was driven by love of a mother naturally (Redzuan \& Abdullah, 2002). Instinct is the impetus to meet the goal of any human is a biological need and become one of the factors driving an individual behavior (Brunstein \& Maier, 2005; Ekman \& Davidson, 1994).

\subsubsection{Self-Sustaining stability}

Maintaining the stability is also among the goals that drive the behavior of human being (Markus \& Kunda, 1986). Man trying to reduce impulses emanating from him/her. The existence encouragement initiated when there is a deficiency in a person. This impulse reduction process focused on the mechanisms of internal motivation. Encourage reduction in motivation theory explains that any human being has the motivation to reduce the inner impulse that had happened. Encouragement which sustained in themselves would be less if some requirement has been fulfilled (Redzuan \& Abdullah, 2002). Someone will try to fulfill his hunger for food. The drive to get food will increase as long as the food looked undiscovered for reducing hunger impulse. Maintaining the stability is among other goals to fulfill the biological requirement and become one of the factors that determine human behavior.

\subsubsection{Motivation of fulfilling the psychosocial needs}

Human sought to achieve psychosocial requirement just like to receive the award or gift (Oatley, 1992). Among the psychosocial needs of the human person are;

\subsubsection{Acquiring incentives}

Incentive is an external stimulus that motivate of individual behavior (Staw, 1976; Kleinginna \& Kleinginna, 1981). There are several criteria of incentives that can stimulate one's actions. The needed incentive is more acceptable than which is not necessary, and positive incentive more approachable than the negative. Someone who does not have friend will sit and enjoy his meal prepared in an event, but person who has many friends will use the opportunity to chat with old friends regardless of the dishes served as having friend for chating is more important to him at that time. Thus, the selection is done by human by the pull of the current incentives and requirements. At the same time, a matter or event that has ever hurt someone in the past was a sure negative incentives shunned by someone (Redzuan \& Abdullah, 2002).

\subsubsection{To Reach an internal satisfaction}

Cognitive theory of motivation splits between intrinsic and extrinsic motivation (Vallerand, \& Reid, 1984; Csikszentmihalyi, \& Nakamura, 1989; Graef, Csikszentmihalyi \& McManama 1983). Intrinsic motivation prompts human to do activities to achieve inner satisfaction, as the results of the implementation of these activities, while extrinsic motivation motivates human to achieve satisfaction from outside such as reward. The research show human will work harder, diligently, conscientious and produce good quality when the task motivation is intrinsic rather than extrinsic motivation (Desa, 2002). Human who is compelled to implement an action due to intrinsic motivation will be able to feel the inner satisfaction after completing a taste satisfaction or results of implementation (McClelland, et.al, 1976).

\subsubsection{Achieving the targeted goals}

Human is driven to execute an action when assuming that his target is actually can be achieved. This phenomenon is explained in the theory of achievement motivation by McClelland. Based on this theory, human is motivated to do something if he feel some goals can be achieved. Conversely, he would not do it if the targeted goals are presumably can not be achieved. A person will feel satisfaction when the targeted goals are achieved (McClelland, et. al, 1976).

Feeling of satisfaction could reached when someone achieve the targeted goals or when the reality meets the expectation. Victor Harold Vroom (b. 1932) a business school professor at the Yale School of Management in his expectancy theory states that someone's behavior is a reflection from decision he took (Hassan, 2001). There are three factors that determine how much someone is willing to try to do a job; a hope, accomplishment and results (Mohd. Dahlan, Baco \& Chua, 2000). An individual will decide to get married for a good expectation resulted from the decision, otherwise the marriage would not be continued 
In lieu of this theory, human hope and predictions about what will happen in the future. Normally, all decisions made by a person are based on what is expected and predicted to occur for the decision taken. When a completed act gave a lot of kindness, a sense of satisfaction will increase, conversely for an opposite situation; the human sense of dissatisfaction will increase. Someone's act or behaves are for its incentive inducement, inner satisfaction and the confident of reaching the targeted goals.

\subsubsection{Environment}

There are some environmental factors that helped driving human behavior. Objects that surround a person like the ecology, architecture, the situation of psychosocial and social factors such as position in the community, education levels and political affiliation are elements of environment that also contributed to the behavior of an individual human being (Mubarok, 1999; Frey, \& Meier, 2004). Environment will also encourage actions and behavior of a human to adapt according it's surrounding (White, 1959).

\subsubsection{Religious}

Religion is the main focus as the need and goal of an individual behavior of (Schoenfeld, 1993). Religion is also a guidance to determine the actions taken by someone. Aspects of faith in Allah, the existence of the Day of Judgment, belief in fate and the provision of Allah and supernatural things are the main catalyst for the movement and behavior of an individual human being (Mubarok, 1999). Human who have religious beliefs will have guidance and define the scope and limits of human behavior and actions.

\subsubsection{Meeting the Bio-psychosocial needs}

Bio-psychosocial goal is one of theory in motivation that combines two objectives, namely the objective needs of biological and psychosocial (Frankel, Quill \& McDaniel, 2004). Abraham Maslow's theory is a theory that explains the goal of the bio-psychosocial human person (Sanford, 1965). Figure 2 below shows Abraham Maslow's theory:

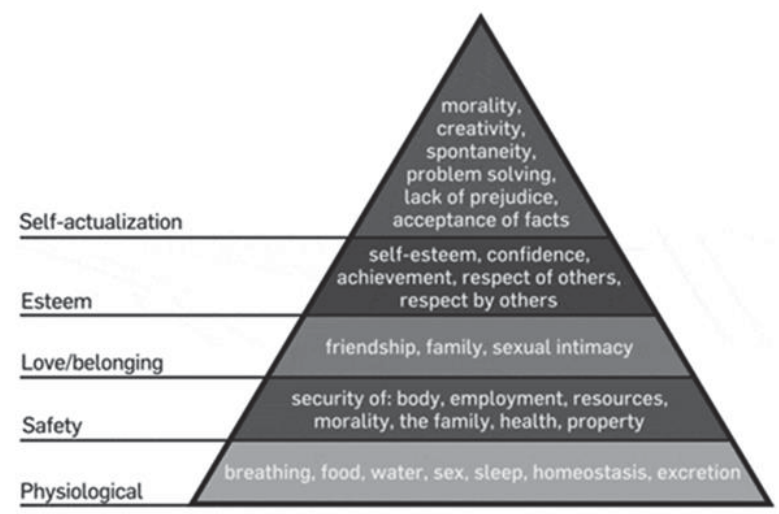

Figure 2. Abraham Maslow's theory

According to Maslow (1987), people will try to meet the five requirements they are, physiological needs, safety, social, esteem and love and self-realization. A failure to fulfill those needs can cause a person to feel uncomfortable and one will constantly strive to meet them. The highlight of the needs of the soul is self-realization that someone is willing to be as desired. If a person fails to comply with this requirement, otherwise he will suffer when someone is able to meet these requirements, he will feel his life exactly meaningful and feel satisfied (Bakar, 2002).

Maslow (1987) also said that there are two motives that drive a man to seek the meaning of life, namely the deficiency motive and the motive for growth. Deficiency motive impulse someone to seek something that is either needed or not available within him. Someone who is alone and lonely needs others to help relieve his loneliness. The concept is 
similar to the situation of a person who lacks food or drink will strive to reduce his appetite motives. Growing motive pushes to get something useful and meaningful and not based on needs. One would have to study hard, driven by a sense to acquire knowledge to help community members in need. Assist members of the public who are in need will produce satisfaction for services rendered will contribute to the more meaningful life. Someone who wants to reach perfection will do something that has meaning to life and this will satisfy his heart and soul (Desa, 2002). Maslow theory suggests the complexity of human needs and stressed it out that when basic needs have not been met, human is relatively will ignore the other higher needs.

\section{Methodology}

The sampling is based on population set to comply with the research (Barreiro \& Albandoz, 2001). The population of muallaf in Selangor comprised 2432 people in both gender, but the total sample for this study comprised 418 people with sampling error at level of 10\%. Each respondent was given booklet of questionnaire containing statement on the issue of their encouragement to embracing Islam. Through this purposive sampling the respondents were selected based on criteria such as the following:

- Respondents were Muslim muallaf who registered in (MAIS) and a residence of the state of Selangor

- Respondents were Muslim muallaf who take the education and dakwah program provided and advised by MAIS Human Development.

\section{Encouragement of Muallaf to Convert to Islam in Selangor: The Findings}

The study found that there are various factors that drive Muallaf in Selangor. The table 1 shows the factors stated by the respondents:

Table 1: Encouragement of Embracing Islam

\begin{tabular}{clc}
\hline No. & Items & Frequency (Person) \\
\hline 1 & Discovering the meaning of life (Religious Factor) & 176 \\
\hline 2 & Finding peace in themselves (Internal Satisfaction Factor) & 138 \\
\hline 3 & As a result of observation (Religious Factor) & 111 \\
\hline 4 & The results of studies on Islam (Religious Factor) & 100 \\
\hline 5 & Islam can solve the problem (Biopsychosocial Factor) & 88 \\
\hline 6 & Get inspiration / dreaming (Religious Factor) & 74 \\
\hline 7 & The effect of mixing with Muslims (Biopsychosocial Factor) & 70 \\
\hline 8 & Marriage of Muslim couples (Psychosocial factors) & 62 \\
\hline 9 & Following the family / Family Converting to Islam (bio-psychosocial factors) & 38 \\
\hline 10 & Easy to get financial aid / welfare ( biopsychosocial factors) & 9 \\
\hline
\end{tabular}

The results show there are three factors driving a respondent to embrace Islam such as to find meaning in life, to find peace with yourself, observations. Based on table 1 above, 176 respondents said they want to find a meaning in their life, and 138 said they want to find peace within themselves, and 111 respondents said among the factor that motivate them to embrace Islam was the result of their long observation towards Islam. The data obtained show the highest factor that drives muallaf to Islam was to find the meaning of life (Ali, 1999).

Other factors which are preferred by respondents in the conversion to Islam was their studies of Islam. They believe Islam can solve their problems, rather than inspiration or dream, and influence their interactions with Muslims (Wohlrab-Sahr, 1999). Based on table 1 above, 88 people were found to be compelled to embrace Islam expressed the belief that the problems encountered can be overcome, while 74 respondents stated their encouragement to embrace Islam as inspiration or dream, and 70 respondents converted to Islam as a result of their friends hood with Muslim.

In relation to the table 1, this study found 38 respondents converted to Islam because of their family, and 9 respondents explained the purpose of their conversion to Islam was as easy to get financial / welfare (Kareena \& Naksewee, 2010; Ensminger, 1997). Moreover, some of them are converted to Islam due to marriage factor (Shatzmiller, 1996, Hassouneh-Phillips, 2001; Jawad, 2006). There are 62 respondents claimed to embrace Islam by marrying Muslim partner. Table 2 shows the encouragement of marriage based on gender. 
Table 2. Gender and Encouragement of Marriage

\begin{tabular}{clcc}
\hline No. & Item & Frequency (Person) & Percentage \\
\hline 1 & Male & 11 & 17.74 \\
\hline 2 & Female & 51 & 82.64 \\
\hline
\end{tabular}

Table 2 shows 62 respondents which consist of 11 respondents (17.74\%) were male, while 51 respondents (82.26\%) were women and they stated that their motivation to embrace Islam because of marriage. This percentage shows that female converts in Selangor more embraced Islam due to marriage than male. Regarding marriage as a factor to convert Islam, the information obtained from the Department of Islamic Affairs State (JHEAINS) recorded that over 80\% muallaf were decided to convert to Islam to marry Muslim partner (Pg. Musa, 2010).

In another study that was done regarding the encouragement of muallaf to accept Islam due to their understanding and the truth of Islam (Jusoh, 2001). This finding came close to the results above which show the highest factor that encourages the conversion in Selangor was to discover the meaning of life. Similarly, in another study, which was conducted entitled Embracing Islam: American Muslims Conversion Narratives of Living in Southern California, the majority of respondents indicated that their main pull factors to convert to Islam is Islam itself as the true religion of Allah.

In other study regarding on factors of converts has concluded that reading media exposure and related Islamic religious has been the biggest factor that encourages them to embrace Islam. This was followed by a second factor, psychosocial that the Muslim community attracted them through example and way of life which also efforts of organizations and missionary organizations that have shed light on Islam indirectly led to open their hearts to choose Islam (Herman, 1998). The discovery matches with the study on religious factor, namely reading and research is the most dominant factor of respondents they had embraced Islam (Taqiyah, 2004). A study was conducted on the factors of acceptance of the converts to Islam found majority of respondents said the main reason they embrace Islam because they are driven by the interaction of Muslims (Mohd. Nasir, 2006).

On the contrary, on a study in 2008 to the non-Muslims either in public Dusun and Murut in Brunei Darussalam to identify the factors of the muallaf group on why it is hard to accept Islam. $68 \%$ of respondents said that Islam is not much different from other religions, $30 \%$ said the family disagrees to convert to Muslim, $14 \%$ Islam is a difficult religion, $8 \%$ said the customary practice cannot be conducted if converted to Islam, $7 \%$ said Islamic preachers can not win their heart, $5 \%$ said that Islam is scary and 0\% stated that is hard to become happy (Ahim, 2010).

Based on the studies it clearly show that in Selangor, the dominant factor why muallaf decided to embrace Islam due to this religion to achieve the meaning of life, followed by the biological need for peace, the observation and study of religion or to resolve the problem faced, followed by psychosocial factors such as mixing with Muslims, marriage and family and lastly by a factor bio-psychosocial which is to gain the financial and welfare assistance.

\section{Conclusion}

Based on the encouragement factors for muallaf to convert to Islam, the truth in Islam can be gained directly or through research, observation and inspiration or dream become major encouragement for Muslim converts to Islam in Selangor. The absence of information and do not receive accurate information about Islam were the factors that delayed the acceptance of da'wah efforts by Islamic groups.

Attention and efforts should be intensified to attempt descriptions of Islam towards the people who are not embraced Islam yet. These efforts also can remedy misconceptions or misunderstandings non muslim towards Islam that causes them to abstain or be afraid to reach out to Muslims. Encouragement aspects in the form of Psychosocial and bio psychosocial have been undertaken by MAIS in particular and all those involved should be maintained even can be improved to encourage muallaf to choose Islam as their faith. Hence, letting those who are not embraced with Islam to find Islam trough their natural instinct only, or just feeling of shortage when they are not convert to Islam will cause the process of Islamization become stagnant.

\section{References}

Ahim, R. (2010). Faktor Pemelukan Islam Dalam Masyarakat Dusun Dan Murut Di Brunei Darussalam. In Proceeding Seminar Kebangsaan Saudara Kita: Isu Dan Cabaran Semasa [Proceeding of National Seminar on Our Brother: Current Issues and Challenges]. Pulau Pinang, Malaysia: USM. 
Al-Zuhaily, W. (1998). Al-Tafsir al-Munir Fi al-Aqidah Wa al-Syariah Wa Al-Manhaj. Vol. 9. Beirut: Dar al-Fikr.

Ali, K. (1999). The journey from the secular to the sacred: Experiences of native British converts to Islam. Social Compass, 46(3), 301312.

Anon. (1970). Mu'jam al-Faz al-Qur'an al-Karim. Cairo: al-Hai'ah al-Misriyyah al-'Ammah Li-Ta'lif Wa al-Nashr.

Bakar, A. A. (2002). Psikologi personaliti individu [Individual personality psychology]. Shah Alam, Malaysia: Karisma Publications.

Barreiro, P. L., \& Albandoz, J. P. (2001). Population and sample. Sampling techniques. Management Mathematics for European Schools MaEusch (994342-CP-1-2001-1-DECOMENIUS-C21.

Brunstein, J. C., \& Maier, G. W. (2005), Implicit and self-attributed motives to achieve: Two separate but interacting needs. Journal of Personality and Social Psychology, 89, 205-222.

Carlson, N. R. (2000). Physiology of Behavior. Boston: Allyn and Bacon.

Carver, C. S., \& Scheier, M. F. (2003). Three human strengths. A psychology of human strengths: Fundamental questions and future directions for a positive psychology, 87-102.

Dennet, D. C. (1950). Conversion and the poll tax in early Islam. Harvard historical monographs. XXII, 120-121.

Desa, A. (2002). Psikologi Untuk Golongan Profesional [Psychology for Professionals]. Malaysia: McGraw Hill Sdn. Bhd.

Ekman, P., \& Davidson, R. J. (1994). The Nature of Emotion. Oxford: Oxford University Press.

Ensminger, J. (1997). Transaction costs and Islam: Explaining conversion in Africa. Journal of Institutional and Theoretical Economics (JITE), 4-29.

Frankel, R., Quill, T., \& McDaniel, S. (2004). The Biopsychosocial Approach: Past, Present, Future. The Permanente Journal, 8(3), 75.

Frey, B. S., \& Meier, S. (2004). Social comparisons and pro-social behavior: Testing conditional cooperation in a field experiment. American Economic Review, 1717-1722.

Harackiewicz, J. M., Barron, K. E., Carter, S. M., Lehto, A. T., \& Elliot, A. J. (1997), Predictors and consequences of achievement goals in the college classroom: Maintaining interest and making the grade. Journal of Personality and Social Psychology, 73, 12841295.

Hassan, A. (2001). Psikologi Moden Untuk Bakal Pendakwah [Modern psychology For Coming Preacher]. Kuala Lumpur: PTS Publications \& Distributors Sdn. Bhd

Hassouneh-Phillips, D. S. (2001). "Marriage is Half of Faith and the Rest is Fear Allah" Marriage and Spousal Abuse Among American Muslims. Violence Against Women, 7(8), 927-946.

Herman, I. (1998). Nilai, Persepsi Jangkaan Saudara Baru Cina Terhadap Masyarakat Dan Agama Islam. In Don, A. G., \& Salamon, H. H. (Eds.). Dakwah Kepada Non-Muslim Di Malaysia: Konsep, Metode dan Pengalaman [Preaching To The Non-Muslims in Malaysia: Concepts, Methods and Experiences]. Bangi, Malaysia: Universiti Kebangsaan Malaysia.

Huffman, K. et.al (2005). Living Psychology. USA: John Wiley \& Sons, Inc.

Husain, M. G. (1996). Psychology and Society in Islamic Perspective. Kuala Lumpur: Institute of Objective Studies.

Jawad, H. (2006). Female Conversion to Islam. Women embracing Islam: Gender and conversion in the West, 153.

Jusoh, N. (2001). Mengapa Kami Memeluk Islam [Why We Embrace Islam]. Shah Alam, Malaysia: DNJ Consultant Sdn. Bhd.

Kareena, A. B. \& Naksewee, S. (2010). Peranan Ustaz Dalam Bidang Dakwah Kepada Non Muslim Di Wilayah Chiangrai Thailand: Pendekatan dan Pendidikan. In Proceeding Seminar Kebangsaan Saudara Kita: Isu Dan Cabaran Semasa [Proceeding of National Seminar on Our Brother: Current Issues and Challenges]. Pulau Pinang, Malaysia: USM.

Kleinginna Jr, P. R., \& Kleinginna, A. M. (1981). A categorized list of motivation definitions, with a suggestion for a consensual definition. Motivation and emotion, 5(3), 263-291.

Kose, A. (1996). Conversion to Islam: a study of native British converts. USA: Routledge.

Markus, H., \& Kunda, Z. (1986). Stability and malleability of the self-concept. Journal of personality and social psychology, $51(4), 858$.

Maslow, A. H. (1943). A Theory of Human Motivation. Psychological Review, 50, 370-396.

Maslow, A. H. (1987). Motivation and Personality. New York: Harper \& Row.

McClelland, D. C., Atkinson, J. W., Clark, R. A., \& Lowell, E. L. (1976). The achievement motive. USA: Appleton Century Crofts, Inc.

Millikan, R. G. (1984). Language, Thought, and Other Biological Categories. Cambridge, MA: MIT Press.

Mohamed, M. N. (1992). Pengantar Psikologi: Satu Pengenalan Asas Kepada Jiwa Dan Tingkah Laku Manusia [Introduction to Psychology: A Basic Introduction To The Soul And Human Behavior]. Kuala Lumpur: Dewan Bahasa dan Pustaka.

Mohd Nasir, R. A. (2006). Faktor-faktor Penerimaan Mualaf Terhadap Agama Islam: Satu Kajian Di PERKIM Jalan Ipoh [The Reception factors of Muallafs to Islam: A Study In PERKIM Jalan Ipoh]. Unpublished Thesis, International Islamic University College Selangor.

Mohd. Dahlan Hj. A. Malek, Baco, B. S., \& Chua, B. S. (2000). Teori-teori motivasi dalam psikologi industri dan organisasi [Motivational theories in industrial and organizational psychology]. Sabah, Malaysia: Universiti Malaysia Sabah.

Moore, J. (2008). Conceptual foundations of radical behaviorism. NY: Sloan.

Mubarok, A. (1999). Jiwa Dalam Al-Quran [The Soul In Quran]. Jakarta: Penerbit Paramadina.

Oatley, K. (1992). Best Laid Schemes: The Psychology of Emotions. Cambridge: Cambridge University Press.

Pg Musa, P. I. (2010). Prosedur Pemelukan Islam Bagi Tujuan Perkahwinan Di Negeri Sabah: Kajian Kes Umi Kalthum Hwa Abdullah @ Hwa Fui Sun Dengan Ketua Pendaftar Muallaf Jabatan Hal Ehwal Agama Islam Negeri Sabah. In Proceeding Seminar Kebangsaan Saudara Kita: Isu Dan Cabaran Semasa [Proceeding of National Seminar on Our Brother: Current Issues and Challenges]. Pulau Pinang, Malaysia: USM.

Piaget, J. (1970). Genetic epistemology. New York: Columbia. 
Qutb, S. (1998). Fi Zilal al-Quran. Vol. 3. Cairo: Dar al-Mashruq.

Redzuan, M. \& Abdullah, H. (2002). Psikologi[Psychology] . Malaysia: McGraw-Hill Sdn. Bhd.

Redzuan, M. (2001). Psikologi Sosial [The Social Psychology]. Serdang: Universiti Putra Malaysia.

Sanford, F. H. (1965). Psychology: A Scientific Study of Man. USA: Wadsworth Publishing Company.

Schoenfeld, W. N. (1993). Religion and human behavior. Boston: Authors Cooperative.

Shatzmiller, M. (1996). Marriage, family, and the faith: Women's conversion to Islam. Journal of Family History, 21(3), 235-266.

Seng, A. W (2009). Murtad Jangan Pandang Sebelah Mata [Apostate: Do not Look in One Eye]. Kuala Lumpur: Mustread Sdn. Bhd.

Staw, B. M. (1976). Knee-deep in the big muddy: A study of escalating commitment to a chosen course of action. Organizational behavior and human performance, 16(1), 27-44.

Taqiyah, A. H. (2004). Faktor Kecenderungan Saudara Kita Memeluk Islam: Satu Kajian Di Darul Ukhuwah [The Factors Trend of Our Brother in Embracing Islam: A Study In Darul ukhuwah]. Unpublisehd Thesis, Faculty of Education, University Technology Malaysia, Johor.

Tarimin, M. et al. (2010). Agihan Zakat Dan Program Pembangunan Muallaf: Statistik Lembaga Zakat Selangor. In Proceeding Seminar Dakwah Kebangsaan Saudara Kita: Isu Dan Cabaran Semasa [Proceeding of National Seminar on Our Brother: Current Issues and Challenges]. Pulau Pinang: USM, p. 373.

Vallerand, R. J., \& Reid, G. (1984). On the causal effects of perceived competence on intrinsic motivation: A test of cognitive evaluation theory. Journal of Sport Psychology, 6(1), 94-102.

Csikszentmihalyi, M., \& Nakamura, J. (1989). The dynamics of intrinsic motivation: A study of adolescents. Research on motivation in education, 3, 45-71.

Graef, R., Csikszentmihalyi, M., \& McManama Gianinno, S. (1983). Measuring intrinsic motivation in everyday life. Leisure Studies, 2(2), 155-168.

Weiner, B. (1992). Human Motivation: Metaphors, Theories And Research. USA: Sage Publications, Inc.

White, R. W. (1959). Motivation reconsidered: the concept of competence. Psychological review, 66 (5), 297.

Wohlrab-Sahr, M. (1999). Conversion to Islam: Between syncretism and symbolic battle. Social Compass, 46(3), 351-362. 